\title{
MODEL CONTEXT BASED LEARNING (CBL) UNTUK MENGEMBANGKAN KETERAMPILAN BERPIKIR KRITIS SISWA PADA PRAKTIKUM PEMBUATAN SABUN
}

\author{
Sari ${ }^{1}$ dan Syfa Nurohmah ${ }^{1}$ \\ 1 Program Studi Pendidikan Kimia Jurusan Pendidikan MIPA \\ Fakultas Tarbiyah dan Keguruan \\ Universitas Islam Negeri Sunan Gunung Djati Bandung, Indonesia \\ Jl. A.H. Nasution No. 105, Bandung 40614 \\ e-mail: riechemistry@gmail.com
}

\begin{abstract}
ABSTRAK
Model pembelajaran CBL adalah proses mengajar menggunakan pendekatan kelompok dimana proses dilakukan dalam bentuk bekerja bersama-sama untuk menciptakan konsep dan membawa siswa fokus terhadap peristiwa atau masalah yang ada. Keterampilan berpikir kritis perlu dikembangkan sebagai wahana penemuan dan pengembangan konsep, prinsip dan teori dalam memahami aplikasi koloid pada pembuatan sabun. Tujuan penelitian ini yaitu menganalisis keterampilan berpikir kritis siswa setelah pembelajaran dengan model $C B L$ pada praktikum pembuatan sabun. Metode yang digunakan yaitu penelitian kelas dengan subjek siswa kelas XI IPA MA Ar-Rosyidiyah. Keterampilan berpikir kritis siswa untuk setiap kelompok prestasi yakni kelompok prestasi tinggi mendapat nilai 89,50 dengan kategori baik sekali, kelompok prestasi sedang mendapat nilai 76,28 dengan kategori baik dan kelompok prestasi rendah mendapat nilai 78,75 dengan kategori baik. Hasil penelitian ini menunjukkan bahwa pembelajaran dengan menerapkan model $C B L$ dapat mengembangkan keterampilan berpikir kritis siswa.
\end{abstract}

Kata Kunci: Model pembelajaran $C B L$, keterampilan berpikir kritis, praktikum pembuatan sabun.

\begin{abstract}
CBL learning model is the process of teaching using a group approach where the process is done in the form of working together to create a concept and bring the students to focus on specific events or issues. Critical thinking skills need to be developed as a vehicle for the discovery and development of concepts, principles and theories in understanding the application of colloid on soap making. The purpose of this study to analyze the critical thinking skills of students after learning lab model with CBL on soap making. The method used is the subject of research grade students XI MA Ar-Rosyidiyah. Critical thinking skills of students for each class of the achievements of high achievement group scored 89.50 with excellent category, group achievements were scored 76.28 with both categories and groups of underachievement scored 78.75 with both categories. The results of this study showed that learning by applying the model CBL can develop students' critical thinking skills.
\end{abstract}

Keywords: CBL learning model, Critical thinking skills, soap making.

DOI: http://dx.doi.org/10.15575/jta.v1i2.1235 


\section{PENDAHULUAN}

Ilmu kimia merupakan produk yaitu pengetahuan kimia yang berupa fakta, teori, prinsip dan hukum, juga merupakan temuan saintis dan proses atau kerja ilmiah (Depdiknas, 2003:7). Sedangkan menurut Chang (2005:3) kimia adalah ilmu yang mempelajari materi dan perubahannya. Berdasarkan kedua definisi di atas dapat dilihat bahwa konsep kimia begitu luas, mulai dari konsep yang sederhana sampai konsep yang sangat kompleks, juga dari konsep yang terlihat konkret sampai konsep yang begitu abstrak untuk dipahami.

Salah satu konsep kimia tersebut yaitu konsep koloid. Salah satu aplikasi konsep koloid dalam kehidupan sehari-hari yakni sabun yang digunakan sebagai pembersih kotoran pada tubuh, pakaian, maupun benda-benda lainnya. Molekul sabun terdiri atas rantai hidrokarbon yang panjang. Hidrokarbon tersebut terdiri atas atom karbon dengan gugus yang sangat polar atau ionik pada salah satu ujungnya. Rantai karbon bersifat hidrofobik larut dalam minyak sementara ujung polarnya yang bersifat hidrofilik larut dalam air (Wade, 2013:1207).

Berbagai sabun dapat dibuat bermacammacam jenis, bentuk, warna, bahan dasar, dan zat tambahan lainnya yang bermanfaat dengan cara yang mudah karena menggunakan alat dan bahan sederhana, seperti praktikum di laboratorium. (Suryana, 2013:34). Praktikum digunakan untuk melihat persoalan dan mengembangkan pola, konsep, teori yang berpotensi meningkatkan penalaran serta penunjang proses belajar mengajar untuk menemukan prinsip (Yunita, 2009:3).

Keterampilan berpikir kritis merupakan sebuah proses sistematis dan jelas yang memungkinkan siswa untuk menggunakannya dalam kegiatan mental seperti merumuskan dan memecahkan suatu masalah, mengambil keputusan, melakukan penelitian ilmiah, menganalisis bukti, asumsi, logika, dan bahasa yang mendasari pernyataan orang lain (Johnson, 2014:185).
Keterampilan berpikir kritis bukan merupakan suatu keterampilan yang dapat berkembang dengan sendirinya seiring dengan perkembangan fisik manusia. Tetapi keterampilan ini harus dilatih melalui pemberian stimulus yang menuntut seseorang untuk berpikir kritis. Dengan demikian pengembangan keterampilan berpikir kritis dalam pembelajaran kimia tidak dapat dilakukan dengan cara mengingat dan menghapal konsep-konsep, tetapi dengan mengintegrasikan, mengaplikasikan, dan mengkomunikasikan konsep-konsep yang telah dimiliki.

Berdasarkan studi pendahuluan yang telah dilakukan ketika Praktik Pengalaman Lapangan (PPL) dan wawancara terhadap guru kimia di MA Ar-Rosyidiyahmengatakan bahwa keterampilan berpikir kritis siswa perlu dikembangkan. Pernyataan tersebut terbukti saat pembelajaran berlangsung bahwa kegiatan proses pembelajaran kimia lebih terfokus untuk mengingat prinsip dan hukum kimia yang berkontribusi pada penguasaan konsep, kurang terfokus pada pengembangan berpikir kritis siswa.

Mengingat keterampilan berpikir kritis perlu dikembangkan, penulis berpendapat bahwa kegiatan pembelajaran kimia di sekolah seharusnya dibuat lebih bervariasi dengan menerapkan model pembelajaran yang sesuai sehingga pemahaman siswa terhadap materi semakin maksimal. Salah satu alternatif model pembelajaran yang dapat mengembangkan keterampilan berpikir kritis ialah dengan menggunakan model Context Based Learning (CBL) karena model ini dapat membantu siswa mengembangkan keterampilan berpikirnya.

Berdasarkan latar belakang yang telah dikemukakan, maka rumusan masalah dalam penelitian ini adalah bagaimana keterampilan berpikir kritis siswa setelah pembelajaran pada praktikum pembuatan sabun melalui model Context Based Learning(CBL)? Penelitian ini bertujuan untuk mengetahui bagaimana keterampilan berpikir kritis siswa setelah pembelajaran pada praktikum 
pembuatan sabun melalui model Context Based Learning (CBL).

\subsection{Model pembelajaran $C B L$}

Model $C B L$ adalah proses mengajar menggunakan pendekatan kelompok dimana proses dilakukan dalam bentuk bekerja bersama-sama untuk menciptakan konsep dan membawa siswa fokus terhadap peristiwa atau masalah yang ada (Trimmer, et al., 2009:1).Berdasarkan hasil penelitian Jong (2006:6) menjelaskan bahwa tahapan pembelajaran model $C B L$ adalah tahap questions, answers, selecting informations, applications.

\subsection{Keterampilan berpikir kritis}

Keterampilan berpikir kritis merupakan sebuah proses sistematis dan jelas yang memungkinkan siswa untuk menggunakannya dalam kegiatan mental seperti merumuskan dan memecahkan suatu masalah, mengambil keputusan, melakukan penelitian ilmiah, menganalisis bukti, asumsi, logika, dan bahasa yang mendasari pernyataan orang lain (Johnson, 2014:185). Menurut Ennis (1985) keterampilan berpikir kritis memiliki 5 indikator, kelima indikator tersebut adalah memberikan penjelasan sederhana, membangun keterampilan dasar, menyimpulkan, membuat penjelasan lebih lanjut, menentukan strategi dan taktik.

\subsection{Aplikasi koloid pada pembuatan dan cara kerja sabun}

Sabun merupakan campuran garam logam alkali dari asam lemak yang mengandung garam $C_{16}$ dan $C_{18}$, juga beberapa karboksilat berbobot atom rendah melalui proses reaksi saponifikasi (McMurry, 2015:809). Dahulu, pembuatan sabun dibuat dari lelehan lemak kambing yang dipanaskan bersama ekstrak abu kayu (mengandung basa) sebelum ada lindi (natrium hidroksida) terhidrolisis menjadi gliserol dan garam natrium. Lapisan air yang mengandung gliserolberfungsi untuk melembabkan (gugus hidroksil berikatan dengan hidrogen mencegah terjadinya penguapan) dipisah dengan penyulingan dan dimurnikan dalam air bersih mendidih dengan menambahkan $\mathrm{NaCl}$ atau $\mathrm{KCl}$ untuk mengendapkan garam karboksilat murni. Sabun yang mengendap dikeringkan, lalu diberi zat-zat tambahan sesuai keinginan (McMurry, 2015:810).

Sabun digunakan sebagai agen pembersih karena dapat mengemulsi minyak (kotoran) dalam air yang dapat dibuang melalui pembilasan. Kepala asam lemak yang bermuatan (-) akan larut dalam air dan ekornya akan larut dalam minyak (Syukri, 1999:465). Kemampuan ini disebabkan dua sifat sabun, pertama rantai hidrokarbon molekul sabun larut dalam zat nonpolar, seperti tetesan minyak. Kedua, ujung anion molekul sabun tertarik pada air, ditolak oleh ujung anion molekul sabun dari tetesan minyak, sebab sabun-minyak tolak-menolak, maka minyak tidak dapat bergabung, tapi tersuspensi.

\section{Gambar 1.1 Misel sabun melarutkan partikel minyak dalam air}

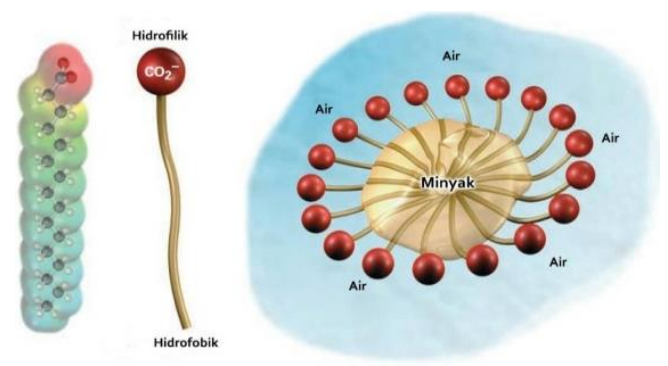

\section{METODE PENELITIAN}

Metode penelitian yang digunakan adalah metode penelitian kelas. Penelitian kelas ini dilakukan untuk memperbaiki proses pembelajaran dan meningkatkan kualitas hasil pembelajaran siswa seperti mengetahui keberhasilan siswa setelah mengikuti pembelajaran, melacak kemajuan prestasi siswa, mengecek ketercapaian kemampuan siswa, mendeteksi kesalahan ketika siswa belajar, dan lain sebagainya.

\subsection{Subyek penelitian}

Subyek pada penelitian ini adalah siswa kelas XI IPA MA Ar-Rosyidiyah Bandung. Adapun karakterisktik kelas XI IPA yaitu berjumlah 30 
orang terdiri dari 14 orang siswa laki-laki dan 16 orang siswa perempuan.Siswa yang berjumlah 30 orang ini dikelompokkan menjadi tiga kelompok, yaitu kelompok tinggi, kelompok sedang, dan kelompok rendah.

\subsection{Instrumen penelitian}

Dalam penelitian ini menerapkan beberapa instrumen, diantaranya tes keterampilan berpikir kritis, kisi-kisi tes keterampilan berpikir kritis, dan rubrik penilaian keterampilan berpikir kritis.

\section{HASIL DAN PEMBAHASAN 3.1 Hasil penelitian}

Proses pembelajaran setelah praktikum pembuatan sabun selanjutnya setiap siswa diberikan soal yang sebelumnya telah disiapkan oleh peneliti. Hal ini digunakan untuk memudahkan peneliti dalam mengetahui pemahaman konsep yang telah dipelajari dan mengetahui keterampilanberpikir kiritis yang dimiliki siswa setelah dilakukan proses pembelajaran dengan model Context Based Learning ( $C B L$ ).

Soal tes keterampilan berpikir kritis tersebut berisi pertanyan-pertanyaan yang harus dijawab oleh setiap siswa. Pertanyaan tersebut berguna untuk menguatkan siswa dalam memahami konsep dan mengembangkan keterampilan berpikir kritis siswa setelah melakukan pembelajaran dan praktikum pembuatan sabun dengan model Context Based Learning (CBL). Pengisian soal pemahaman konsep tersebut diisi setelah dilaksanakannya praktikum yang hasilnya akan dikategorikan sangat baik dengan nilai 100-80, baik 70-79, cukup 60-69, kurang 5559 dan sangat kurang dari 54-0.

Setiap siswa dikelompokkan berdasarkan kelompok prestasi yakni kelompok tinggi berjumlah 8 orang, kelompok sedang berjumlah 14 orang, dan kelompok rendah berjumlah 8 orang berdasarkan nilai ulangan harian kimia sebelumnya. Soal tes keterampilan berpikir kritis ini berjumlah 6 pertanyaan yang masing-masing berisikan indikator pembelajaran dan indikator keterampilan berpikir kritis.

Persentase pencapaian pemahaman siswa pada praktikum pembuatan sabun dengan konsep sistem koloid secara keseluruhan sangat baik. Rata-rata keseluruhan indikator kelompok prestasi tinggi mendapat nilai dengan kategori sangat baik yakni 89,50, kelompok prestasi sedang mendapat nilai dengan kategori baik yakni 76,28 dan kelompok prestasi rendah mendapat nilai 78,75 dengan kategori baik. Analisis hasil soal tes keterampilan berpikir kritis berdasarkan kelompok prestasi dapat dilihat pada gambar grafik 3.1 di bawah ini:

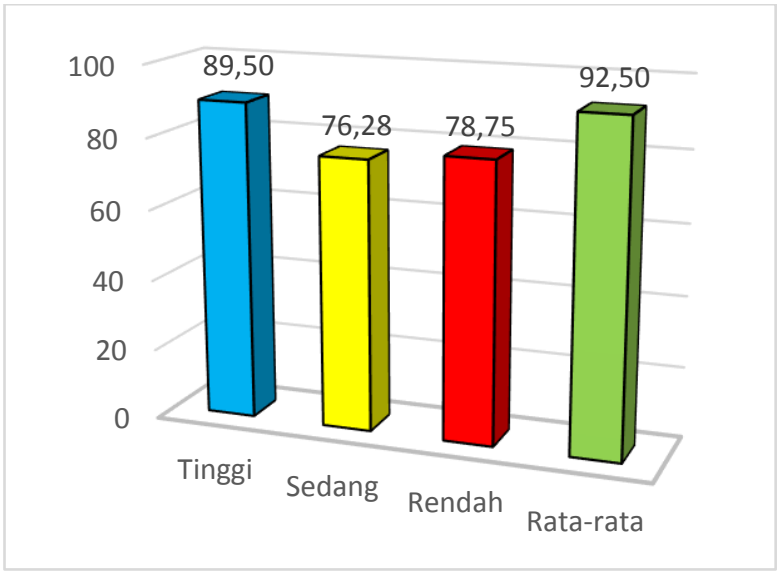

\section{Gambar 3.1 Grafik nilai rata-rata indikator keterampilan berpikir kritis siswa berdasarkan kelompok prestasi}

\subsection{Pembahasan}

Indikator keterampilan berpikir kritis yang dikembangkan pada tiap soal tes keterampilan berpikir kritis yaitu (memberikan penjelasan sederhana) pada nomor 1b, (membangun keterampilan dasar) pada nomor 2 dan 4, (menyimpulkan) pada nomor 5 dan 6, (membuat penjelasan lebih lanjut) nomor $3 \mathrm{a}$ dan 3b, (menentukan strategi dan taktik) pada nomor $1 a$.

Hasil soal tes keterampilan berpikir kritis siswa pada beberapa indikator soal memiliki 
data yang terlihat sedikit ekstrim yakni nilai rata-rata kelompok rendah lebih tinggi dari kelompok sedang.

Data mengenai keterampilan berpikir kritis pada indikator menentukan strategi dan taktik diukur dari hasil skor soal nomor 1a dengan nilai kelompok tinggi sebesar 100, kelompok sedang 85,66 dan kelompok rendah 91,66 berada pada kategori sangat baik. Data ekstrim tersebut hasil rata-rata kelompok prestasi rendah mendapat nilai 91,66 sedangkan kelompok sedang mendapat nilai 85,66 . Kelompok rendah mengungguli nilai kelompok sedang, sebab kelompok rendah dipengaruhi oleh kelompoknya ketika diskusi sehingga mempunyai semangat yang besar agar mereka bisa mendapatkan nilai yang tinggi dan tidak tertinggal oleh siswa lain. Hubungan berkelompok pada prinsipnya banyak dipengaruhi orang lain,karena belajar melalui interaksi sosial dengan orang lain bisa mendapat kemajuan dalam prestasi.

Salah satu data yang sedikit ekstrim lagi yakni data mengenai keterampilan berpikir kritis pada indikator membuat penjelasan lebih lanjut diukur dari hasil skor soal nomor $3 a$ dengan nilai kelompok tinggi sebesar 81 berada pada kategori sangat baik, kelompok sedang sebesar 80 dan kelompok rendah sebesar 80,66 berada pada kategori sangat baik. Data ekstrim tersebut hasil rata-rata kelompok prestasi rendah mendapat nilai 80,66 sedangkan kelompok sedang mendapat nilai 80 . Kelompok rendah mengungguli nilai kelompok sedang.Sesuai dengan pernyataan Duranti dan Goodwin (dalam Smits, et al., 2011:439) bahwa Context Based Learning (CBL) memiliki peraturan dalam proses pembelajaran yang mengharuskan siswa fokus terhadap peristiwa atau fenomena yang berkaitan dengan materi pelajaran yang sedang dibahas.

Data hasilrata-rata keseluruhan, kelompok prestasi tinggi mendapat nilai dengan kategori sangat baik yakni 89,50, kelompok prestasi sedang mendapat nilai dengan kategori baik yakni 76,28 dan kelompok prestasi rendah mendapat nilai 78,75 dengan kategori baik.Hal tersebut dirasa pembelajaran menjadi lebih berarti, karena mereka mampu menghubungkan lebih baik kegunaan sabun dengan konsep koloid yang dapat dilihat dari kejadian kehidupan seharihari disekitar mereka, sesuai dengan pendapat yang dikemukakan olehTrianto (2013:171) bahwa pembelajaran akan lebih bermakna jika siswa diberi kesempatan mengetahui dan terlibat aktif menemukan konsep dari fakta yang dilihat dari lingkungan, maka dengan itu dapat meningkatkan pemahaman siswa.

\section{KESIMPULAN}

Berdasarkan uraian diatas maka penulis menarik kesimpulan bahwa keterampilan berpikir kritis siswa setelah pembelajaran dengan model Context Based Learning (CBL) pada praktikum pembuatan sabun menghasilkan nilai yang berbeda-beda untuk setiap indikator keterampilan berpikir kritis. Rata-rata keseluruhan indikator kelompok prestasi tinggi mendapat nilai dengan kategori baik sekali yakni 89,50, kelompok prestasi sedang mendapat nilai dengan kategori baik yakni 76,28 dan kelompok prestasi rendah mendapat nilai 78,75 dengan kategori baik.

\section{DAFTAR PUSTAKA}

Chang, R. (2005). Kimia Dasar: Konsep-konsep inti. Jilid // (Ed.Ketiga).Terjemahan oleh M.A. Martoprawiro, dkk. Jakarta: Erlangga.

Depdiknas. (2003). Kurikulum 2004 Standar Kompetensi Mata Pelajaran Sains dan Kimia SMU dan MA. Jakarta: Depdiknas.

Ennis, R. H. (1985). A Logical Basis for Measuring Critical Thinking Skills. Educational Leadership, 43(2), 44-48.

Johnson, E.B. (2014). Contextual Teaching \& Learning: Menjadikan Kegiatan Belajar Mengajar Mengasyikan dan Bermakna. 
Terjemahan oleh Ibnu Setiawan.

Bandung: Kaifa.

Jong, O.D.(2006). Context-Based Chemical Education: How to Improve It?. Makalah. Disajikan pada ICCE 19, Seoul.

McMurry, J. (2015). Organic Chemistry: with Biological Applications. United State of America: Cengage Learning.

Smits, L.G.A.D.P., Taconic, R., dan Jochems,W.M.G. (2011). Mapping Context- Based Learning Environments: The Contruction of an Instrument. Learning Envion Res (2013). 16:437-462.

Suryana, D. (2013). Membuat Sabun, Cara Membuat Berbagai Sabun Padat dan Cair. [Online]. Tersedia: www.books.google.co.id. [Diakses 1 November 2015].

Syukri. (1999). Kimia Dasar 2. Bandung: ITB.

Trianto. (2013). Model Pembelajaran Terpadu. Jakarta: Bumi Aksara.

Trimmer, W.,Laracy, K., dan Love-Gray, M.,Whitireia Community Polytechnic. (2009). Seeing The Bigger Picture Context-Based Learning. Good Pratice Publication Grants, 1-6.

Wade. (2013). Organic Chemistry. United State of America: Pearson.

Yunita. (2009). Panduan Pengelolaan Laboratorium Kimia. Bandung: CV Insan Mandiri. 